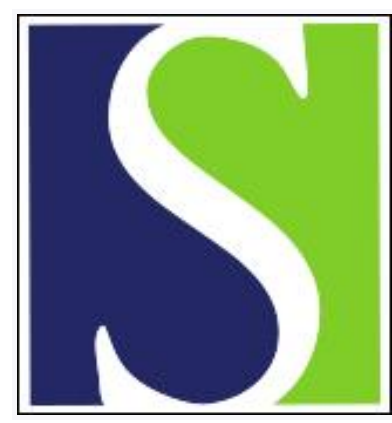

Scand J Work Environ Health 1982;8(2):108-112

https://doi.org/10.5271/sjweh.2489

Issue date: Jun 1982

Malignant mesothelioma in Turkish immigrants residing in Sweden.

by Boman G, Schubert V, Svane B, Westerholm P, Bolinder E, Rohl AN, Fischbein $A$

Key terms: asbestos; environmental exposure; erionite; immigrant; malignant mesothelioma; mesothelioma; Sweden; Turkey; zeikute

This article in PubMed: www.ncbi.nlm.nih.gov/pubmed/6291146

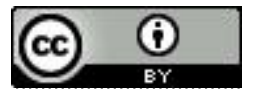




\title{
Malignant mesothelioma in Turkish immigrants residing in Sweden
}

\author{
by Gunnar Boman, MD, ' Vivianne Schubert, MD, ${ }^{1}$ Bertil Svane, MD, ${ }^{1}$ \\ Peter Westerholm, MD, ${ }^{2}$ Erik Bolinder, MD, ${ }^{2}$ Arthur N Rohl, PhD, ${ }^{3}$ \\ Alf Fischbein, $\mathrm{MD}^{3}$
}

\begin{abstract}
BOMAN G, SCHUBERT V, SVANE B, WESTERHOLM P, BOLINDER E, ROHL AN, FISCHBEIN A. Malignant mesothelioma in Turkish immigrants residing in Sweden. Scand $j$ work environ health 8 (1982) 108-112. Mesothelioma is a rare neoplasm in the general population, but it is strongly associated with previous asbestos exposure. The endemic occurrence of this disease in two villages in central Turkey has raised the question of whether the inhalation of naturally occurring zeolite dust may also be a factor in the development of mesothelioma. During the past few years a large portion of the inhabitants of one of the two villages of concern has immigrated to Sweden. This report presents three cases of malignant pleural mesothelioma and the results of a chest radiographic survey among these immigrants. Mineralogical analysis of lung tissue specimens from two of the cases revealed the presence of both zeolite and asbestos minerals and therefore suggested a synergistic effect involving both types of minerals. The importance of close medical surveillance of this high-risk population is emphasized, as is the possibility that similar cases appear in other countries because of increased migration.
\end{abstract}

Key terms: asbestos, environmental exposure, erionite, malignant mesothelioma, zeolite.

Malignant mesothelioma is a rare tumor in most countries, but its incidence seems to be rising $(6,12)$. Since the early report by Wagner et al (11) a number of studies has confirmed the relationship between this tumor and previous exposure to asbestos $(4,5,10)$. In some cases, however, no history of significant occupational or environmental asbestos exposure can be obtained. This lack raises the question of whether some other agent - fibrous or nonfibrous - may also contribute to the development of mesothelioma.

A remarkable clustering of cases of malignant mesothelioma in two small

1 Karolinska Hospital, Stockholm, Sweden.

2 Medical Department, Swedish Trade Union Confederation, Stockholm, Sweden.

3 Environmental Sciences Laboratory, Department of Community Medicine, Mount Sinai Medical Center, New York, New York, United States.

Reprint requests to: Prof G Boman, Department of Lung Medicine, University Hospital, S-750 14 Uppsala, Sweden. villages (Karain 4 and Tuzköy) in central Turkey has recently been investigated by Baris et al $(2,3)$. These authors suggest that inhalation of fibrous erionite - one of many zeolite minerals - may be the cause. Their results were given considerable attention in the Swedish news media and caused concern among the more than 100 immigrants from Karain in Sweden. Representatives of the Turkish workers in Sweden contacted the Confederation of Swedish Trade Unions for advice and requested assistance in clarifying the situation. This request resulted in a chest radiographic survey of the Turkish immigrant population residing in the Stockholm metropolitan area. Concomitantly, three cases of malignant pleural mesothelioma were observed in Turkish immigrants from Karain. In the following re-

4 The name of the village Karain is said to mean "pain in the abdomen" in Turkish and therefore indicates a long history of illness in this region. 
port we present clinical, pathological, and mineralogical aspects of the three cases and the results of the chest radiographic survey.

\section{Case histories}

\section{Case 1}

A 50-year-old male, born in Karain, immigrated to Sweden in 1966, where he worked in a restaurant. He smoked 20 cigarettes per day. He had been mildly hypertensive since 1976 but was otherwise healthy. During the last three months of 1978 he complained of a dull pain in the back of his chest, lost $7 \mathrm{~kg}$, and became dyspneic. A chest radiograph showed marked pleural thickening on the right side, and he was admitted to a hospital in January 1979. Bronchoscopy, sputum cytology, and thoracocentesis did not yield a conclusive diagnosis. A provisional diagnosis of tuberculosis was made, and chemotherapy was given until the cultures for tuberculosis became negative. In August 1979 the patient was readmitted because his symptoms had worsened and his chest roentgenograms showed evidence of progression. A specimen obtained by fine needle lung biopsy showed malignant cells, but no further classification was possible. Anticancer treatment was not administered. The patient's condition deteriorated further, and in October 1979 he was transferred to his home in Turkey where he soon died. No autopsy was performed.

\section{Case 2}

Case 2 comprised a 38-year-old male who was born in Karain and lived there un- til 1954. From 1954 to 1966 this man lived in other parts of central Turkey. $\mathrm{He}$ immigrated to Sweden in 1966 and worked in various restaurants until 1976; since then he has worked as a butcher. $\mathrm{He}$ has no history of occupational exposure to asbestos and has never smoked. He was generally healthy. In January 1979 he complained of a dull pain in the left side of his chest. In July 1979 a left-sided pleurisy with pleural effusion was found, and he was hospitalized for evaluation. Thoracoscopy after thoracocentesis revealed patchy, jelly-like layers on the lung surface, but no certain histological diagnosis was achieved. Malignancy was suspected however. A chest radiograph showed extensive pleural thickening on the left side without parenchymal changes. Computerized axial tomography of the abdomen did not indicate any abnormality.

Explorative thoracotomy was performed in November 1979. Massive pleural adhesions with marked pleural thickening were observed. After dissection from the thoracic wall no masses were felt in the lung. Specimens of the pleura and the lung were submitted for histological examination and for mineralogical analysis. Malignant pleural mesothelioma exhibiting an epithelial (tubulopapillary) form was diagnosed. No ferruginous bodies were seen in the lung specimens. The results of the mineralogical analysis (7) are presented in table 1.

After the operation, the patient remained well but some chest pain persisted. Follow-up chest radiographs showed no change. However in January 1981 an isolated metastasis in the left thoracic wall was found and surgically removed. In addition, radiotherapy (40 Gy)

Table 1. Results of transmission electron microscopic and microchemical analyses of lung tissue from two Turkish individuals.

\begin{tabular}{lccccc}
\hline & \multicolumn{2}{c}{ Percentages of fibrous minerals present in lung tissue } \\
\cline { 2 - 5 } & Zeolites & $\begin{array}{c}\text { Amphibole } \\
\text { (tremolite } \pm \\
\text { anthophyllite) }\end{array}$ & Chrysotile & Other & Total \\
\cline { 2 - 5 } Case 2 & 75 & 9 & 5 & 5 & 94 a \\
Case 3 & 64 & 27 & 9 & (pyroxene-?) & 100 \\
\hline
\end{tabular}

a Remainder were other natural fibers, including glass. 
combined with chemotherapy (bleomycin, cyclophosphamide and fluorouracil) was given from April to June 1981.

\section{Case 3}

A 25-year-old man who was born in Karain moved to Stockholm in 1975 where he worked mostly in restaurants. He smoked sporadically. He sought medical advice because of pains in his chest, but the medical records have not been retrieved. In 1976 he returned to Turkey to do military service. He then fell ill and was diagnosed as having mesothelioma. He died in 1980 at the age of 30 . No autopsy was performed, but lung and pleural tissue (nontumorous) was obtained for histological and mineralogical analyses through the courtesy of Prof YI Baris of the Hacettape University, Faculty of Medicine, Ankara. Interstitial fibrosis and chronic fibrous pleuritis were found upon histological examination. The results of our mineralogical analysis (7) are shown in table 1.

\section{Radiographic survey}

\section{Subjects and methods}

In cooperation with the Turkish Workers Union in Stockholm an invitation to participate in a radiographic survey was sent to 112 immigrants. Only persons born in Karain in 1965 or earlier were invited.

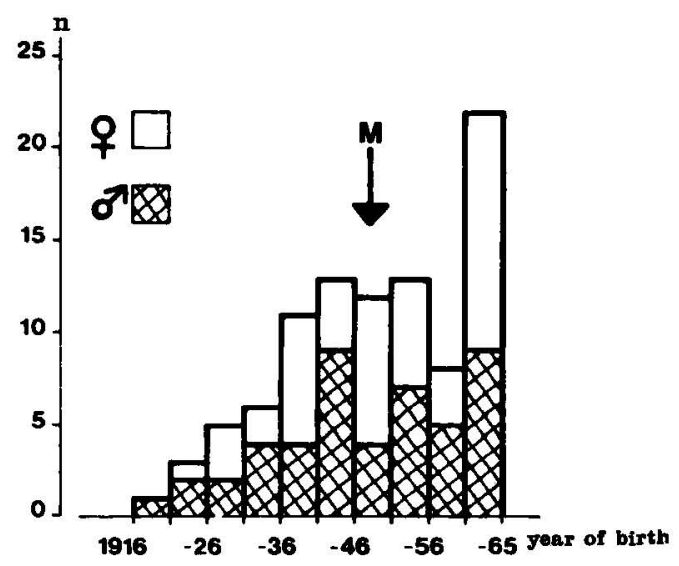

Fig 1. Participants in the chest radiographic survey of immigrants from Karain $(\mathrm{N}=94)$, according to sex and year of birth. The arrow indicates the median for both sexes.
The survey was conducted during 1980 . At the examination past medical and occupational histories were recorded on a questionnaire. Four chest roentgenograms were taken (one posteroanterior, one lateral and two oblique projections). All films and previous films, when available, were scrutinized by the same radiologist. Persons with respiratory symptoms or abnormal films were examined clinically.

Ninety-four individuals $(47$ men \& 47 women) participated in the study. Their age distribution is shown in fig 1 . Most of them had worked in agriculture in Karain and had lived there on the average for 22 a. Although the majority of them had immigrated directly from Karain to Stockholm, a few had resided in other places in Turkey as well. In Sweden 10 men and 35 women were currently or previously employed as janitors, 23 individuals as factory workers, and 26 in restaurants. Only one was occupationally exposed to asbestos. Twenty-seven of the men were smokers, and 14 of them smoked more than 20 cigarettes per day. None of the women smoked.

\section{Results}

Sixty-six of the 94 persons examined had previously undergone one or more chest radiograph examinations in Sweden. Eleven persons ( 7 men \& 4 women) had abnormal chest radiographs. Nine of them had findings reflecting old problems of no current interest (eg, old tuberculosis, healed rib fractures); five of these findings were observed on previous films. Two males had findings of current concern, a 56-year-old gardener without known exposure to asbestos but with small calcified pleural plaques, known since 1975 , and an asymptomatic 33-year-old man with a solitary lung infiltrate not observed on previous films from 1971. The latter finding necessitated further clinical evaluation. No radiographic findings suggestive of mesothelioma were observed.

Recent onset of cough was reported by five women and four men. Six women and one man complained of shortness of breath on exertion, while one woman and three men reported intermittent chest pains. Clinical examination did not reveal any significant chest disorder in these symptomatic individuals. 
Symptoms from other organ systems were common, eg, backache, which was reported by 10 women and 2 men, and "stomach pain," reported by 7 women and 7 men. Fear of future cancer development was expressed by many of the examined; it was often exacerbated by previous cancer deaths in the family.

\section{Discussion}

Our finding of three cases of malignant mesothelioma during a few years of observation of a population of fewer than 150 individuals from the village of Karain, Turkey, is remarkable and corroborates the high incidence rate of this tumor reported by Baris et al $(1,3)$. The clinical course and radiographic findings of our first case are compatible with malignant mesothelioma, although no specific histological verification was obtained. However, the other two cases had histologically proven mesotheliomas. The relatively young ages of the second and third patients at the onset of the disease is of interest. With persons occupationally exposed to asbestos, there is usually a long period of clinical latency before mesothelioma is observed - often $25-45$ a. However, the present three cases suggest childhood exposure to the etiological agent(s) (10). The second patient is still alive and well 3 a after the appearance of the first symptoms; this is considered a relatively long survival time for an otherwise highly malignant tumor that is typically associated with a survival of six months to a year, even after "early diagnosis."

Our radiographic survey was organized primarily to bring help and reassurance to an exposed and concerned immigrant group. The identification of this unique high-risk population, however, is of great significance, and its future management may provide important information for the early detection and treatment of malignant disease, of mesothelioma in particular. We therefore suggest close monitoring of this population. Fortunately, no cases of serious lung disease were found during this initial study, although one case with typical pleural plaques was observed. The chest films obtained constitute a valuable data base for comparative studies in the future. It is known that many Turkish immigrants, when they become seriously ill, repatriate (like our first case), which may complicate future epidemiologic studies. Those who immigrated to Sweden may also constitute the healthier portion of the population in Karain, those who are well enough and ambitious enough to emigrate. The likelihood of finding similar cases among individuals of Turkish origin in other European countries, because of migration, should be recognized.

The results of the mineralogical analysis of the Iung specimens from the two patients, shown in table 1 , is pertinent for the etiology of mesothelioma. The identification of zeolite in lungs is important and verifies that the fibrous zeolite (erionite) dust in Karain is respirable and retained in the lung (9).

Furthermore, the results are of interest because they imply that several fibrous etiologic agents may be involved, namely, asbestiform minerals (chrysotile and tremolite) and fibrous zeolite (erionite). In addition another laboratory has reported recently on the mineralogical content in lung tissue of mesothelioma patients in a nearby village, Tuzköy (9). Both zeolite fibers and asbestiform amphibole fibers were found.

Finally, all of these findings are in accordance with those reported by Rohl et al (8). These authors found both erionite and asbestiform minerals in lung tissue and in environmental samples (rock, settled dust, etc) in the mesothelioma villages of Karain, Tuzköy, and Sarihidir. Thus the consistent findings of mixed fibrous dusts in both lung tissues and environmental samples raise the question of whether a synergistic effect involving both asbestos and zeolite may be operating. Because of the unusually high incidence rate of mesothelioma among these individuals at risk, we ascribe a strong carcinogenic potential to the etiologic agent(s), whether they act synergistically or separately. Experimental studies are warranted in order to clarify these suggestions.

\section{Acknowledgments}

Our gratitude is due to Ms S Annenberg and Mr M Kohn for their secretarial and editorial assistance. 
This work was supported in part by grant ES-00928 from the National Institute of Environmental Health Sciences Center.

\section{References}

1. Baris YI, Artvinli M, Sahin AA, Savas T, Erkan ML. Étude du mésothéliome pleural malin, de la pleurésie fibrosante chronique et des plaques pleurales liées à l'environnement en Turquie. Rev fr mal respir 7 (1979) $687-694$.

2. Baris YI, Sahin AA, Ozeani MI, Kerse I, Ozen E, Kolacan B, Altinöors M, Göktepeli A. An outbreak of pleural mesothelioma and chronic fibrosing pleurisy in the village of Karain/Urgüp in Anatolia. Thorax 33 (1978) 181-192.

3. Baris YI, Simonato L, Saracci R, Artvinli M, Skidmore JW. Malignant mesothelioma and radiological chest abnormalities in two villages in central Turkey: An epidemiological and environmental investigation. Lancet (1981) 984-987.

4. Cochrane JC, Webster J. Mesothelioma in relation to asbestos fibre exposure: A review of 70 cases. S afr med j 54 (1978) 279-281.

5. Edge JR, Choudhury SL. Malignant mesothelioma of the pleura in Barrow-in-
Furness. Thorax 33 (1978) 26-30.

6. Elmes PC, Simpson MJC. The clinical aspects of mesothelioma. Q j med 15 (1976) $427-449$.

7. Langer AM, Pooley FD. Identification of single asbestos fibers in human tissues. In: International Agency for Research on Cancer. Biological effects of asbestos. Lyon 1973, pp 119-125.

8. Rohl AN, Langer AM, Baris YI, Lilis R, Moncure G, Fischbein A, Selikoff IJ. Endemic pleural disease associated with mixed fibrous dust exposure in Turkey. Science (in press)

9. Sebastien P, Gaudichet A, Bignon J, Baris YI. Zeolite bodies in human lungs from Turkey. Lab invest 44 (1981): 5, 420-456.

10. Selikoff IJ. Lung cancer and mesothelioma during prospective surveillance of 1249 asbestos insulation workers, 1963-1974. Ann ny acad sci 271 (1976) 448-456.

11. Wagner JC, Sleggs CA, Marchand P. Diffuse pleural mesothelioma and asbestos exposure in the North Western Cape Province. $\mathrm{Br} \mathrm{j}$ ind med 17 (1960) 260-271.

12. Asbestos-related neoplasms. Semin oncol 8 (1981): 3, 241-343.

Received for publication: 4 March 1982 